\title{
DUKUNGAN POLITIK ELIT ADAT KECAMATAN KURANJI KEPADA IRWAN PRAYITNO-NASRUL ABIT PADA PILKADA SUMBAR TAHUN 2015
}

\author{
Febri Rahmat \\ Jurusan Ilmu Politik, Fisip, Universitas Andalas \\ Email: febrirahmat97@gmail.com
}

\begin{abstract}
Abstrak
Penelitian ini berangkat dari adanya keterlibatan niniak mamak yang tergabung di KAN Pauh IX Kecamatan Kuranji dalam mendukung Irwan Prayitno dan Nasrul Abit pada Pilkada Sumbar Tahun 2015. Tujuan penelitian untuk mendeskripsikan dan menganalisis alasan keterlibatan niniak mamak KAN Pauh IX Kecamatan Kuranji dan bagaimana bentuk keterlibatannya dengan menggunakan teori elit dan konsep keterlibatan elit tradisional dalam Pilkada. Kemudian penelitian ini menggunakan pendekatan kualitatif deskriptif dengan tipe studi kasus. Penelitian ini menemukan, niniak mamak yang tergabung di KAN Pauh IX Kecamatan Kuranji terlibat dalam mendukung Irwan Prayitno dan Nasrul Abit baik secara individu maupun KAN secara kelembagaan. Keterlibatan dilakukan melalui tiga jaringan kekuasaan. Pertama, jaringan kekuasaan melalui kemampuan pribadi, kedua, melalui otoritas tradisional dan ketiga, jaringan kekuasaan berdasarkan pengakuan dari rekan-rekan mereka dengan menganugerahkan gelar sangsako di suku. Kemudian bentuk keterlibatan. Pertama, memberikan gelar Datuak kepada Irwan Prayitno dan pembentukan dewan pembina suku Tanjuang Sumatera Barat. Kedua, melakukan konsolidasi. Ketiga, niniak mamak sebagai penghubung kepentingan antara Irwan Prayitno, niniak mamak dan anak kemenakan yang ada di Kecamatan Kuranji. Keempat, niniak mamak mensosialisasikan Irwan Prayitno kepada anak kemenakannya. Kelima, mobilisasi. Keenam, deklarasi kebulatan tekad.
\end{abstract}

Kata Kunci: Elit Tradisional ; Keterlibatan Elit ; Pilkada.

\begin{abstract}
This research departs from the involvement of niniakmamak who are members of KAN Pauh IX Kuranji District in supporting IrwanPrayitno and Nasrul Abit in the 2015 West Sumatra local election. The purpose of this research is to describe and analyze the reasons for the involvement of the niniak mamak KAN Pauh IX, Kuranji District and what forms of involvement. The theoretical foundation used is elite theory and the concept of involvement of traditional elites in the local election. Then this study uses a descriptive qualitative approach with a case study type.. This research found that the niniak mamak incorporated in KAN Pauh IX Kuranji District were involved in supporting IrwanPrayitno and NasrulAbit both individually and KAN as an institution. Engagement is carried out through three power networks. First, the network of power through personal abilities that are recognized by the community in the village. Second, through traditional authority. Third, the power network is based on the recognition of their peers by conferring the title of sangsako in the tribe. Then the form of involvement. First, the awarding of the title of Datuak to IrwanPrayitno and the formation of the Tanjuang West Sumatra tribal council. Second, the two consolidate to reach mutual agreement. Third, niniak mamak as a liaison between the interests of IrwanPrayitno, niniak mamak and nephew in Kuranji District. Fourth, niniak mamak socialized IrwanPrayitno to his niece's child. Fifth, mass. Sixth, niniak mamak made a declaration.
\end{abstract}

Keywords : Traditional Elite ; Elite Involement ; Local Election 


\section{PENDAhuluan}

Pelaksanaan Pemilihan Kepala Daerah (Pilkada) telah membuka peluang besar untuk berbagai elemen di tingkat lokal, terutama elit lokal untuk ikut terlibat dalam proses politik tersebut. Keterlibatan elit lokal tidak terlepas dari upaya yang digunakan oleh politisi untuk memenuhi kepentingannya seperti melalui nilai-nilai primordial dan identitas. Dalam hal ini Nurhasim yang dikutip oleh Amrianto mengatakan bahwa, elit lokal dijadikan tameng yang tidak logis namun rasional bagi elit-elit yang mempunyai kepentingan memperjuangkan apa yang diinginkan, maka tidak heran apabila elit-elit lokal seperti tokoh adat, kepala suku, agama, dijadikan tameng dalam memuluskan kepentingan dalam Pemilukada (Amrianto, Skripsi, 2015: 5).

Dalam hal ini seorang ahli yaitu Cohen yang dikutip oleh Asrinaldi bahwa "kelompok etnis menyesuaikan dengan realitas baru dengan reorganisasi adat sendiri, atau dengan mengembangkan kebiasaan baru di bawah simbol tradisional, sering menggunakan norma-norma tradisional dan ideologi untuk meningkatkan kekhasan dalam waktu situasi kontemporer," (Asrinaldi, Jurnal, 2017: 3). Artinya perkembangan sistem pemerintahan oleh negara yang menggunakan pemilu atau pilkada dalam memilih pemimpinnya telah mempengaruhi kehidupan sosial masyarakat khususnya elit adat yang notabenenya adalah mengurusi persoalan adat istiadat namun sudah mulai bergeser pada tatanan politik praktis.

Keterlibatan elit lokal dalam proses politik pada konteks Pilkada dapat dilihat dari beberapa daerah, seperti keterlibatan elit tradisional dalam dinamika politik lokal pada Pilkada di Kabupaten Wakatobi Tahun 2014, dalam fenomena ini pemanfaatan ketergantungan masyarakat terhadap bangsawan Wakatobi yang dikarenakan faktor ekonomi, oleh karena itu orientasi politik masyarakat tidak bisa berpaling dari keputusan politik bangsawan Wakatobi tersebut (Amrianto, Skripsi, 2015: 5).

Kemudian fenomena ini juga terjadi di Provinsi Sumatera Barat khususnya di Pilkada Pasaman Barat Tahun 2010, pada fenomena ini adanya peran dari elit tradisional yang dalam hal ini adalah niniak mamak yang memberikan dukungan secara terbuka melalui surat pernyataan dukungan terhadap pasangan calon Baharuddin dan Syahrul (Aulia S Putra, Skripsi, 2014: 1). Dari fenomena ini dapat dilihat adanya upaya pemanfaatan tokoh adat yang notabenenya sebagai pemuka adat bertugas mengurusi persoalan-persoalan yang berkaitan dengan adat, kemudian dimodifikasi perannya menjadi alat untuk memperoleh suara dalam Pilkada.

Indikasi keterlibatan ini dapat dilihat melalui acara kebulatan tekad niniak mamak yang tergabung dalam Kerapatan Adat Nagari (KAN) Kecamatan Kuranji yang secara terbuka menyatakan dukungan terhadap pasangan calon Irwan Prayitno-Nasrul Abit 
sebagai gubernur dan wakil gubernur dalam Pilkada Sumatera Barat pada Tahun 2015. Kebenaran hal ini dapat dilihat melalui pernyataan yang disampaikan oleh ketua KAN Pauh IX Kecamatan Kuranji Ahmad As Datuk Maharajo Basa dalam acara deklarasi kebulatan tekad tersebut, bahwa "usai pernyataan kebulatan tekad ini, maka semua niniak mamak yang ada akan menghimbau anak kemenakan mereka untuk memberikan dukungan dan memilih pasangan nomor urut 2, Irwan Prayitno-Nasrul Abit. Himbauan tersebut akan disampaikan secara berantai dari satu anak kemenakan ke anak kemenakan lainnya," (Irwan-Prayitno.com, 4 Desember 2015). Kemudian hal ini kembali dipertegas melalui pernyataan Ahmad As Datuk Maharajo Basa dalam salah satu berita yang berjudul Niniak Mamak KAN Pauh V dan IX Sepakat Dukung IP-NA, bahwa "mudahmudahan IP-NA bisa melanjutkan programnya ke depan, karena saat ini pasangan nomor urut 2 masih terbaik," (Minangkabau News, 2019, 5 desember 2015).

Dalam keterlibatan niniak mamak ini terlihat indikasi melibatkan KAN secara kelembagaan, yang seharusnya lembaga KAN notabenenya adalah lembaga adat yang menghimpun pemimpin dari berbagai suku seharusnya tidak dilibatkan dalam kontestasi politik, karena hal ini berpotensi mengganggu independensi KAN yang seharusnya sebagai pemersatu dalam kehidupan masyarakat dalam nagari hal ini kemudian diperkuat oleh Asrinaldi yang mengatakan "keterlibatan penghulu dalam aktivitas politik akan menurunkan marwah institusi adat tersebut," (Asrinaldi, 2017:182). Maka peneliti melihat hal ini menjadi suatu fenomena yang patut dikaji melalui penelitian ini. Indikasi ini dapat dilihat dari beberapa faktor sebagai berikut, pertama acara deklarasi dihadiri oleh pengurus dan niniak mamak yang tergabung didalam KAN Kecamatan Kuranji dan juga acara ini dibuka oleh Ketua KAN Kecamatan Kuranji Ahmad As Datuk Maharajo Basa dalam hal ini status ketua KAN sejatinya akan terus melekat pada pribadi ketua KAN dimanapun dia berada.

Permasalahan muncul ketika terjadi deklarasi terbuka oleh niniak mamak di Kecamatan Kuranji yang tergabung dalam KAN yang seharusnya secara ideal tidak membawa lembaga tersebut dalam konstelasi politik praktis. Oleh karena itu yang menjadi permasalahan dan perlu dilihat pada penelitian ini adalah, mengapa niniak mamak yang tergabung dalam KAN Pauh IX terlibat dalam mendukung pasangan calon Irwan Prayitno-Nasrul Abit pada Pilkada Sumatera Barat Tahun 2015 dan bagaimana bentuk keterlibatan niniak mamak tersebut? Maka tujuan dilaksanakannya penelitian ini adalah untuk mendeskripsikan dan menganalisis keterlibatan niniak mamak yang tergabung di KAN Pauh IX Kecamatan Kuranji dalam upaya mendukung pasangan calon Irwan Prayitno dan Nasrul Abid di Kecamatan Kuranji pada Pilkada Sumatera Barat 2015. 


\section{Review Literature}

Pertama, Penelitian Aulia Satria yang berjudul "Peran Elit Tradisional Dalam Pemenangan Pasangan Baharudin pada Pemilukada Pasaman Barat Tahun 2010". Penelitian ini menggunakan teori elit dan konsep peran. Metodologi yang digunakan dalam penelitian ini adalah kualitatif. Penelitian ini menjelaskan bahwa elit tradisional yang dalam kasus ini adalah niniak mamak Pasaman Barat mempunyai peran yaitu: pertama, niniak mamak sebagai tim sukses bagi pasangan Baharuddin-Syahrul. Kedua, niniak mamak mempunyai peran sebagai penghubung antara pasangan BaharuddinSyahrul dengan cucu kamanakan. Selain itu niniak mamak juga dapat secara langsung mengajak dan mengarahkan сиси kamanakan untuk memilih pasangan BaharuddinSyahrul (Aulia S Putra,Skripsi,2014:1).

Penelitian ini mampu menganalisis dan menguraikan dengan rinci bagaimana bentuk keterlibatan yang dilakukan niniak mamak dalam mendukung Pasaman Barat Baharudin- Syahrul sebagai pasangan calon Bupati dan Wakil Bupati. Namun Penelitian ini agak luput dalam menjelaskan kekuatan otoritas tradisional yang dimiliki niniak mamak dalam melakukan dukungan, maka lebih lanjut perlu mempertegas analisis tentang otoritas tradisional yang digunakan dalam keterlibatannya dalam kontestasi politik praktis.

Kedua penelitian oleh Amrianto yang berjudul "Peranan Elit Tradisional dalam Dinamika Politik Lokal pada Pemilihan Kepala Daerah di Kabupaten Wakatobi 2014". Konsep yang digunakan dalam penelitian ini adalah tentang peranan elit tradisional. Metodologi yang digunakan dalam penelitian ini adalah metode kualitatif deskriptif. Hasil penelitian menunjukkan bahwa dalam bidang ekonomi, adanya hubungan ketergantungan antara masyarakat (massa) dengan bangsawan Wakatobi. Dengan modal ekonomi tersebut mampu menimbulkan hubungan sangat permanen antara keduanya, yang mana dengan kebangsawan tersebut orientasi politik tidak akan berpaling kepada siapapun. Dalam bidang politik, pilihan politik bangsawan Wakatobi ditempatkan sebagai tokoh, dimana keputusan politik akan selalu dipatuhi dan tidak berani dilanggar (Amrianto, Skripsi, 2015: 5).

Dalam penelitian ini Amrianto mampu melihat adanya hubungan yang sematamata hanya terjadi antara elit dengan non elit, namun Amrianto mampu menganalisis dan menjelaskan dengan baik adanya hubungan elit antara elit yang melakukan konsolidasi dalam upaya mempengaruhi masyarakat, namun dalam penelitian ini Amrianto terlalu fokus pada faktor ekonomi sebagai kekuatan yang dimiliki oleh elit tradisional, sedangkan otoritas tradisional yang dimiliki oleh elit tradisional juga sangat berpengaruh terhadap sosial budaya, sehingga dalam hal ini amrianto melihat bahwa masyarakat bisa 
saja tidak terpengaruh ketika sosial budaya di masyarakat bermasalah dengan elit tradisional. Maka diperlukan analisis lebih dalam mengenai kekuatan informal dari berbagai sisi, baik ekonomi, sosial budaya maupun sumber otoritas lainnya.

Ketiga skripsi Indra Kardian mahasiswa Ilmu Politik, FISIP, Universitas Andalas pada tahun 2017 yang berjudul " Peran Elit Tradisional dalam Mendukung Pasangan Calon Independen M Ramlan Nurmatias dan Irwandi Pada Pilkada Kota Bukittinggi Tahun 2015". Penelitian ini mengacu pada teori elit dan konsep peranan elit tradisional untuk mengidentifikasi peranan elit tradisional dalam mendukung pasangan calon independen $\mathrm{M}$. Ramlan Nurmantias dan Irwandi Pada Pilkada Kota Bukittinggi Tahun 2015. Penelitian ini menggunakan pendekatan kualitatif dengan tipe penelitian studi kasus (Indra Kardian, Skripsi, $2015: 8$ ).

Dalam penelitian ini Indra Kardian sangat baik dan terperinci menjelaskan posisi yang diduduki oleh para niniak mamak dalam mendukung Nurmatias-Irwandi, namun dalam penelitian ini Indra Kardian kurang mampu melihat dan menggambarkan hubungan apa yang dibangun oleh niniak mamak dengan pasangan calon hingga niniak mamak ikut secara aktif dalam mendukung Nurmantias-Irwandi dan Indra Kardian tidak melihat bahwasanya niniak mamak secara individu terlibat dalam politik itu merupakan sesuatu yang sah. Dalam penelitian ini Amrianto mampu melihat adanya hubungan yang semata-mata hanya terjadi antara elit dengan non elit, namun Amrianto mampu menganalisis dan menjelaskan dengan baik adanya hubungan elit antara elit yang melakukan konsolidasi dalam upaya mempengaruhi masyarakat.

Keempat jurnal Asrinaldi yang berjudul "Power Network of Penghulu Adat in The Concurrent Regional Election In West Sumatera" dalam penelitian ini menjelaskan tentang jaringan kekuatan Minangkabau penghulu adat di Sumatera Barat. Seperti diketahui di Sumatera Barat, penghulu memiliki posisi strategis di masyarakat Minangkabau. Posisinya di lembaga-lembaga tradisional sangat penting, terutama dalam menjembatani kepentingan masyarakat dalam proses politik dan pemerintahan di nagari. Ini dianggap layak karena penghulu adat mampu mengoptimalkan jaringan kekuasaan mereka dan memanfaatkan lembaga tradisional tempat mereka berkumpul (Asrinaldi, Jurnal, 2017: 3).

Dalam menjelaskan jaringan kekuasaan penghulu, penelitian ini menggunakan tipe deskriptif pendekatan kualitatif. Selanjutnya, penelitian ini menemukan berbagai jenis formasi dalam penghulu jaringan kekuasaan yang berfungsi sebagai dasar untuk keterlibatan mereka dalam proses politik desa. Pertama, pembentukan penghulu jaringan kekuasaan melalui kemampuan pribadi yang diakui oleh masyarakat di desa. Kedua, pembentukan penghulu jaringan kekuasaan melalui otoritas tradisional. Ketiga, pembentukan penghulu jejaring tenaga yang berasal dari tambahan legitimasi pemerintah 
daerah, khususnya bagi penghulu yang dianggap mewakili kepentingan pemerintah daerah di desa. Keempat, pembentukan penghulu jaringan kekuasaan berdasarkan pengakuan dari rekan-rekan mereka dengan menganugerahkan gelar sangsako di suku (Asrinaldi, Jurnal, 2017: 5).

Perbedaan penelitian ini dengan penelitian terdahulu, secara teoritis penelitian ini menggunakan konsep jaringan kekuasan elit tradisional yang dihubungkan dengan konsep keterlibatan elit tradisional dalam Pilkada yang kemudian mampu menemukan alasan dan bentuk keterlibatannya. Penelitian ini menemukan bahwa niniak mamak yang tergabung di KAN Pauh IX Kecamatan Kuranji terlibat dalam mendukung Irwan Prayitno dan Nasrul Abit baik secara individu maupun KAN secara kelembagaan, kemudian ada alasan yang melandasi keterlibatan dan bentuk keterlibatan elit tradisional dalam Pilkada.

\section{Elit Tradisional}

Von Der Mehden dalam Indra Kardian, dia mengklasifikasikan elit tradisional menjadi beberapa kelompok yaitu elit agama, pewaris budaya atau adat istiadat dan golongan bangsawan yang memiliki daulah atau wilayah. "Keberadaan elit tradisional dalam negara berkembang termasuk di Indonesia tetap ada meski terjadi pengurangan pengaruh pengaruh dan otoritasnya dalam era modernisasi," (Indra Kardian, Skripsi, 2015 :30).

Menurut Max Weber yang dikutip oleh Asrinaldi bahwa pada dasarnya "legitimasi yang berlaku dalam otoritas tradisional akan menghasilkan legitimasi dari para pengikutnya karena otoritas / kekuasaan tersebut berasal dari kepercayaan pada kesucian tradisi yang telah berlatih untuk waktu yang lama di masyarakat. Tradisi yang dipraktikkan diyakini memiliki kapasitas untuk membimbing mereka ke tujuan hidup yang diinginkan. Kepercayaan pada kekuatan tradisional berasal dari nilai-nilai yang diyakini masyarakat dan dipraktikkan untuk menjadi budaya dan kebiasaan yang berkembang. Melalui aktualisasi nilai-nilai budaya dan adat, seorang pemimpin memperoleh legitimasi untuk memimpin masyarakat," (Asrinaldi, Jurnal, 2017: 5).

Berdasarkan hal diatas, elit tradisional merupakan bentuk adanya pembagian dan perbedaan kelas didalam kehidupan sosial masyarakat, hal ini membuat adanya dominasidominasi yang didasari oleh legitimasi otoritas yang dimiliki. Otoritas yang dimiliki oleh elit tradisional berasal dari kepercayaan terhadap nilai-nilai tradisi di dalam adat yang kemudian sebagai bentuk aktualisasi nilai-nilai tersebut seseorang akan diserahi legitimasi untuk menjadi pemimpin. Dalam menjalankan kepemimpinan seorang elit tradisional dilandasi oleh legitimasi yang diperoleh melalui otoritas tradisional. 


\section{Elit Tradisional Minangkabau}

Menurut Bustanul Arifin yang dikutip oleh Indra Kardian mengatakan bahwa elit tradisional dalam tradisi Minangkabau ialah kepala kaum yakni Datuak atau penghulu dimana legitimasi diwarisi secara turun temurun berdasarkan garis keturunan matrilineal atau garis keturunan dari ibu. Kepenghuluan dalam Minangkabau di bagi menjadi dua kelarasan yaitu, kelarasan Koto Piliang bertingkat yang paling bawah Penghulu Andiko, Penghulu Suku, Penghulu Pucuk sampai kepada Penghulu Mempelai semua penghulu atau di kenal dengan istilah batangga turun, bajanjang naiak (bertangga turun, berjenjang naik) maksudnya ialah segala permasalahan yang datang dari rakyat atau kemenakan dinaikan dari mamak kepada Penghulu Andiko terus kepada Penghulu Empat Suku baru sampai kepada Penghulu Pucuk dan dialah yang berhak mengambil keputusan (bajanjang naiak). Kelarasan Bodi Caniago tidak bertingkat, tapi sama kedudukannya. Segala permasalahan yang datang diselesaikan dengan baiyo-iyo (musyawarah mufakat atau kesepakatan) (Indra Kardian, Skripsi, $2015: 30-31$ ). Oleh karena itu dalam penelitian ini penulis melihat bahwasanya niniak mamak di Minangkabau merupakan elit tradisional yang muncul dari kalangan adat karena niniak mamak merupakan pemimpin bagi kaumnya masing-masing.

\section{Keterlibatan Elit Tradisional dalam Pilkada}

Huges dalam Asrinaldi menjelaskan bahwa "perkembangan kontemporer menegaskan kekuatan otoritas tradisional saat ini telah mengalami transformasi dalam peran kepemimpinannya dan telah beradaptasi dengan pengaruh global seperti proses demokratisasi yang terjadi di banyak negara," (Asrinaldi, 2017: 181). Ini sejalan dengan penjabaran Cohen dalam bukunya Custom and Politics in Urban Africa: "Dalam satu kasus, sebuah kelompok etnis menyesuaikan diri dengan realitas sosial baru dengan mengadopsi kebiasaan yang dibagi dengan kelompok lain. Dalam kasus kedua kelompok etnis menyesuaikan dengan realitas baru dengan reorganisasi adat sendiri, atau dengan mengembangkan kebiasaan baru di bawah simbol tradisional, sering menggunakan norma-norma tradisional dan ideologi untuk meningkatkan kekhasan dalam waktu situasi kontemporer" (Asrinaldi, 2017: 181). Artinya ada perkembangan dan perubahan atas otoritas tradisional yang dimiliki oleh elit-elit tradisional yang dipengaruhi oleh pengaruh global dan dunia modern tetapi dengan tidak semerta-merta meninggalkan budaya lama.

Asrinaldi membagi keterlibatan ini dalam empat bentuk, yaitu "pertama niniak mamak mensosialisasikan calon sesuai dengan kepentingan penghulu kepada anak kemenakannya, terutama menyangkut calon kepala daerah sesuai dengan yang didukungnya. Kedua penghulu dalam Pilkada juga menjadi penghubung kepentingan kaum dan suku dengan calon kepala daerah yang membutuhkan dukungan dari anak 
kemenakannya di nagari. Ketiga mengarahkan pilihan anak kemenakannya. Keempat, kepemilikan dukungan penghulu adat yang berasal dari anak kemenakannya dalam nagari, juga berimbas pada penguatan legitimasi adat," (Asrinaldi, 2017: 187-189). Menurut Asrinaldi para niniak mamak dalam upaya mendukung pasangan calon melalui jaringan kekuasaan yang dibangun seperti: "pertama, pembentukan penghulu jaringan kekuasaan melalui kemampuan pribadi yang diakui oleh masyarakat di desa. Kedua, pembentukan penghulu jaringan kekuasaan melalui otoritas tradisional. Ketiga, pembentukan penghulu jejaring tenaga yang berasal dari tambahan legitimasi pemerintah daerah, khususnya bagi penghulu yang dianggap mewakili kepentingan pemerintah daerah di desa. Keempat, pembentukan penghulu jaringan kekuasaan berdasarkan pengakuan dari rekan-rekan mereka dengan menganugerahkan gelar sangsako di suku," (Asrinaldi, 2017: 187-189).

Dari penjabaran pemikiran diatas dapat memberikan gambaran keterlibatan elit dalam tatanan kehidupan sosial politik tidak bisa dipisahkan. Niniak mamak yang pada dasarnya mereka yang mempunyai posisi sebagai pemimpin dalam kaumnya tentu mempunyai pengaruh, oleh karena itu sangat memungkinkan untuk mengakomodir kepentingan melalui otoritas yang dimiliki, walau hal tersebut tidak sesuai dengan fungsi dan tugas yang semestinya.

\section{METODE PENELITIAN}

Penelitian ini menggunakan pendekatan kualitatif dengan tipe penelitian studi kasus, yaitu sebuah pendekatan yang berguna untuk menjelaskan fenomena sosial yang ingin diteliti secara mendalam. Menurut John W. Creswell "penelitian kualitatif merupakan metode-metode untuk mengeksplorasi dan memahami makna yang (oleh sejumlah individu atau sekelompok orang) dianggap berasal dari masalah sosial atau Kemanusiaan," (John W. Creswell,2013: 135-136).

\section{HASIL DAN PEMBAHASAN}

\section{Struktur Kedudukan dan Kekuasaan Elit Adat Kecamatan Kuranji}

Von Der Mehden dalam Indra Kardian, dia mengklasifikasikan elit tradisional menjadi beberapa kelompok yaitu elit agama, pewaris budaya atau adat istiadat dan golongan bangsawan yang memiliki daulah atau wilayah. "Keberadaan elit tradisional dalam negara berkembang termasuk di Indonesia tetap ada meski terjadi pengurangan pengaruh pengaruh dan otoritasnya dalam era modernisasi," (Indra Kardian, Skripsi, 2015). Artinya elit tradisional memiliki posisi yang diwariskan melalui otoritas tradisional namun dalam konteks negara modern pengaruh elit tradisional memiliki tantangan tersendiri dengan pengaruh global, namun keberadaan elit tradisional masih tetap diperhitungkan dalam beberapa konteks. 
Dalam konteks adat, keberadaan elit tradisional dapat dilihat melalui etnis Minangkabau, keberadaan elit tradisional ini sangat dipengaruhi oleh keberadaan adat istiadat atau kelestarian budayanya karena dua hal ini berjalan beriringan. Elit tradisional Minangkabau dalam kehidupan masyarakatnya disebut sebagai Datuak atau penghulu, elit tradisional ini memiliki legitimasi berdasarkan garis keturunan dari Ibu, hal ini dikarenakan sistem kekerabatan di Minangkabau menganut sistem matrilineal.

Hal ini sesuai yang disampaikan oleh Bustanul Arifin yang dikutip oleh Indra Kardian yang mengatakan bahwa elit tradisional dalam tradisi Minangkabau ialah kepala kaum yakni Datuak atau penghulu dimana legitimasi diwarisi secara turun temurun berdasarkan garis keturunan matrilineal atau garis keturunan dari ibu. Kepenghuluan dalam Minangkabau di bagi menjadi dua kelarasan yaitu; kelarasan Koto Piliang bertingkat yang paling bawah Penghulu Andiko, Penghulu Suku, Penghulu Pucuk sampai kepada Penghulu Mempelai semua penghulu atau di kenal dengan istilah batangga turun, bajannjang naiak (bertangga turun, berjenjang naik). Artinya segala permasalahan yang datang dari rakyat atau kemenakan dinaikan dari mamak kepada Penghulu Andiko terus kepada Penghulu Empat Suku baru sampai kepada Penghulu Pucuk dan dialah yang berhak mengambil keputusan (bajanjang naiak). Kelarasan Bodi Caniago tidak bertingkat, tapi sama keduduknnya. Segala permasalahan yang datang diselesaikan dengan baiyo-iyo (musyawarah mufakat atau kesepakatan) (Indra Kardian, Skripsi, 2015 : 30-31).

Dalam hal ini, peneliti mengelompokkan niniak mamak atau penghulu sebagai kelompok elit tradisional dalam konteks adat, maka peneliti menamakan penghulu sebagai elit adat. Pengelompokan penghulu sebagai elit karena mereka memiliki otoritas tradisional yang melekat melalui gelar yang dibawa yaitu datuak, melalui otoritas tradisional yang dimiliki sehingga penghulu memiliki tupoksi tersendiri dari kelompok masyarakat lainnya, hal ini tergambar dari pepatah adat Minangkabau yang mengatakan bahwa, penghulu itu didahulukan salangkah, ditinggikan sarantiang.

Berdasarkan Perda Sumbar No. 7 Tahun 2018 Pasal 1 angka 6 tentang Nagari KAN merupakan "lembaga perwujudan permusyawaratan perwakilan tertinggi dalam penyelenggaraan pemerintahan nagari yang keanggotaannya terdiri dari perwakilan niniak mamak, unsur alim ulama, unsur cadiak pandai, unsur bundo kanduang, dan unsur parik paga dalam nagari yang bersangkutan sesuai dengan adat salingka nagari. Hal ini menunjukan bahwa KAN merupakan wadah dimana unsur adat nagari berhimpun mulai dari niniak mamak, alim ulama, cadiak pandai, bundo kanduang dan pemuda sebagai parik paga dalam nagari, namun yang menjadi pemimpin di KAN disini adalah niniak mamak yang sebagai penghulu atau yang bergelar datuak, datuak memiliki otoritas tradisional di wilayah kekuasaan masing-masing. 
KAN secara kelembagaan memiliki eksistensi yang cukup kuat di masyarakat Minangkabau. KAN merupakan tempat dihimpunnya para niniak mamak yang merupakan elit disukunya masing-masing dan KAN memiliki otoritas yang kuat didalam kehidupan sosial masyarakatnya dalam konteks adat istiadat. Hal ini dikarenakan KAN memiliki tugas dan fungsi mengurusi adat istiadat dan mengurusi kehidupan anak kemenakan, seperti halnya mengurusi konflik-konflik harta pusaka dan tanah ulayat.

Namun dalam perkembangannya kedudukan KAN sebagai lembaga adat yang mengurusi persoalan adat istiadat mulai terpengaruh oleh kehidupan modern, hal ini dimungkinkan terjadi karena di salah satu bentuk adat yang ada di Minangkabau ada namanya "adat nan diadatkan" hal ini memiliki arti bahwa kebiasaan baru bisa saja berubah menjadi budaya masyarakat Minangkabau karena menyesuaikan dengan keadaan atau kebiasaan yang baru tersebut. Kemudian seperti yang disampaikan oleh Cohen yang dikutip oleh Asrinaldi bahwa "dalam satu kasus, sebuah kelompok etnis menyesuaikan diri dengan realitas sosial baru dengan mengadopsi kebiasaan yang dibagi dengan kelompok lain. Dalam kasus kedua kelompok etnis menyesuaikan dengan realitas baru dengan reorganisasi adat sendiri, atau dengan mengembangkan kebiasaan baru di bawah simbol tradisional, sering menggunakan norma-norma tradisional dan ideologi untuk meningkatkan kekhasan dalam waktu situasi kontemporer," (Asrinaldi, 2017: 187-189).

Hal ini terlihat pada fenomena adanya dukungan atau kebulatan tekad niniak mamak yang tergabung dalam KAN Pauh IX Kecamatan Kuranji mendukung Irwan Prayitno- Nasrul Abit dalam pemilihan Gubernur Sumbar tahun 2015. Jauh sebelum itu pada pemilihan Gubernur Sumbar tahun 2010 KAN Pauh IX Kecamatan Kuranji juga pernah dinyatakan terlibat dalam mendukung Irwan Prayitno-Muslim Kasim dalam Konteks ini kantor KAN tersebut pernah dijadikan posko relawan untuk Irwan PrayitnoMuslim Kasim. (Zulhendri Ismet, Wawancara, 5 Desember 2019)

Artinya melihat dari kedudukan KAN secara kelembagaan melalui UU maupun secara hukum adat yang merupakan perhimpunan niniak mamak, dalam hal mengurusi persoalan adat istiadat dan kehidupan anak kemenakan, namun dengan adanya sistem pemerintahan formal dan juga sistem pemilihan kepala daerah melalui Pilkada, niniak mamak yang tergabung dalam KAN Pauh IX kecamatan Kuranji mulai terlibat dalam hal tersebut yang pada dasarnya bukanlah tugas dan fungsi dari KAN itu sendiri. Hal ini kemudian berpotensi menggerus tugas dan fungsi utama dari KAN dan kemudian juga berpotensi untuk hadirnya konflik di dalam tubuh KAN secara kelembagaan maupun dikehidupan kaumnya, karena dalam konteks mendukung pasangan calon dalam Pilkada cenderung adanya perbedaan pandangan dan menyangkut kepentingan, tidak terlepas dari kepentingan individu dan kelompok. 


\section{Alasan Keterlibatan Elit Adat Kecamatan Kuranji dalam Mendukung Irwan Prayitno-Nasrul Abit Pada Pilkada Sumbar Tahun 2015}

Cohen yang dikutip oleh Asrinaldi bahwa "kelompok etnis menyesuaikan dengan realitas baru dengan reorganisasi adat sendiri, atau dengan mengembangkan kebiasaan baru di bawah simbol tradisional, sering menggunakan norma-norma tradisional dan ideologi untuk meningkatkan kekhasan dalam waktu situasi kontemporer," (Asrinaldi, Jurnal, 2017: 3). Artinya perkembangan sistem pemerintahan oleh negara yang menggunakan pemilu atau pilkada dalam memilih pemimpinnya telah mempengaruhi kehidupan sosial masyarakat khususnya elit adat yang notabenenya adalah mengurusi persoalan adat istiadat namun sudah mulai bergeser pada tatanan politik praktis.

Nurhasim yang dikutip oleh Amrianto mengatakan bahwa "elit lokal dijadikan tameng yang tidak logis namun rasional bagi elit-elit yang mempunyai kepentingan memperjuangkan apa yang diinginkan, maka tidak heran apabila elit-elit lokal seperti tokoh adat, kepala suku, agama, dijadikan tameng dalam memuluskan kepentingan dalam pemilukada," (Amrianto, Skripsi, 2015: 5). Dari hal ini dapat dilihat bahwa keterlibatan elit adat dalam Pilkada tidak terlepas dari upaya yang dilakukan oleh pasangan calon atau pemangku kepentingan dalam pilkada untuk mendapatkan suara sebanyak banyaknya dan kecendrungan dalam keterlibatan tersebut memiliki alasanalasan tertentu.

Secara eksplisit alasan elit adat atau niniak mamak yang tergabung dalam KAN Pauh IX Kecamatan Kuranji adalah sebagai berikut. Pertama, Irwan Prayitno merupakan putra daerah. Kedua, adanya harapan ketika Irwan Prayitno jadi gubernur akan mengutamakan pembangunan di Kecamatan Kuranji dan terkhusus janjinya membangun kantor KAN Pauh IX Kecamatan Kuranji. Ketiga, Irwan Prayitno sebagai petahana dan memiliki elektabilitas tinggi. Alasan ketiga ini muncul dikarenakan adanya keyakinan niniak mamak dan anak nagari Kecamatan Kuranji bahwa Irwan Prayitno pasti akan menang di Pilkada Sumbar Tahun 2015 dan adanya pandangan ketika tidak mendukung Irwan Prayitno yang diyakini akan menang akan berdampak buruk terhadap yang tidak ikut mendukung karena kepentingan mereka tidak akan diakomodir oleh Irwan Prayitno

\section{Bentuk Dukungan Politik Elit Adat Kecamatan Kuranji Kepada Irwan Prayitno dan Nasrul Abit Pada Pilkada Sumbar Tahun 2015}

\section{Jaringan Kekuasan Elit Adat dalam Pilkada}

Upaya pembentukan jaringan kekuasaan yang dilakukan oleh niniak mamak menurut Asrinaldi ada empat yaitu, "pertama pembentukan penghulu jaringan kekuasaan melalui kemampuan pribadi yang diakui oleh masyarakat di desa. Kedua, pembentukan penghulu jaringan kekuasaan melalui otoritas tradisional. Ketiga, pembentukan penghulu 
jejaring tenaga yang berasal dari tambahan legitimasi pemerintah daerah, khususnya bagi penghulu yang dianggap mewakili kepentingan pemerintah daerah di desa. Keempat, pembentukan penghulu jaringan kekuasaan berdasarkan pengakuan dari rekan-rekan mereka dengan menganugerahkan gelar sangsako di suku," (Asrinaldi, 2017: 187-189).

Dalam penelitian ini keterlibatan niniak mamak Kecamatan Kuranji terlihat melalui beberapa jaringan kekuasaan yang dimiliki oleh niniak mamak tersebut. Pertama, melalui melalui kemampuan pribadi yang diakui oleh masyarakat di desa. Maka untuk dalam upaya mempengaruhi anak kemenakannya, niniak mamak harus membentuk hubungan patron-klien yang merujuk pada hubungan saling ketergantungan antara niniak mamak dan anak kemenakannya. Dalam penerapan ini menurut Asrinaldi niniak mamak harus memenuhi beberapa kondisi. "Pertama, jika penghulu ini memiliki latar belakang yang baik dan sering kali menjadi tempat bergantung anak kemenakannya, maka mobilisasi dukungan terhadap calon kepala daerah lebih efektif dilakukan di nagari tersebut. Kedua, penghulu juga membuat pola hubungan yang rasional objektif dengan anak kemenakannya karena status sosial penghulu yang juga bertindak sebagai intelektual (cerdik pandai) di nagari. Ketiga, penghulu secara tidak langsung menjadi tim di lapangan," (Asrinaldi, 2017: 193-194).

"Secara sempurna niniak mamak tidak seluruhnya memiliki elemen-elemen dasar tersebut. Secara pendidikan, kebanyakan dari mereka tidak memiliki latar pendidikan yang tinggi namun ada beberapa yang sudah Doktor, secara ekonomi pada umumnya mereka pedagang dan ada yang tidak bekerja. Namun mereka memiliki hubungan silaturahmi yang kuat dengan anak kemenakan dan mereka mampu membuat kesepakatan dan mempengaruhi anak kemenakannya untuk mendukung dan menyokong Irwan Prayitno dan Nasrul Abit di Pilkada Sumbar Tahun 2015, hal ini peneliti melihat dikarenakan niniak mamak saling mengisi kekurangannya masing-masing dan juga secara adat mereka masih cukup kuat dan juga dikenal dengan kekompakannya. Selain itu niniak mamak ikut turun kelapangan, menghimbau anak kemenakan dan mensosialisasikan Irwan Prayitno di acara-acara yang ada di nagari," (Suardi Datuak Rajo Bujang, Wawancara, 3 Desember 2019).

Kedua, melalui otoritas tradisional, Weber menjelaskan bahwa "legitimasi yang berlaku dalam otoritas tradisional akan menghasilkan legitimasi dari para pengikutnya karena otoritas/kekuasaan tersebut berasal dari kepercayaan pada kesucian tradisi yang telah berlatih untuk waktu yang lama di masyarakat. Tradisi yang dipraktikkan diyakini memiliki kapasitas untuk membimbing mereka ke tujuan hidup yang diinginkan. Kepercayaan pada kekuatan tradisional berasal dari nilai-nilai yang diyakini masyarakat dan dipraktikkan untuk menjadi budaya dan kebiasaan yang berkembang. Melalui aktualisasi nilai-nilai budaya dan adat, seorang pemimpin memperoleh legitimasi 
untuk memimpin masyarakat," (Asrinaldi, Jurnal, 2017: 3). Artinya elit tradisional dalam menjalankan peran dan fungsinya dilandasi oleh otoritas tradisional yang diperoleh melalui nilai-nilai yang diakui oleh masyarakatnya yang kemudian diaktualisasikan.

Melalui hal ini niniak mamak dinilai memiliki kemampuan untuk mempengaruhi kaumnya, kemudian hal ini terlihat pada kemampuan mobilisasi yang digunakan untuk menghadiri kampanye Irwan-Prayitno dan Nasrul Abit. Karena menurut Asrinaldi "ketika pemilihan umum diadakan, fungsi otoritas tradisional yang menggunakan elite ini sangat dicari oleh para kandidat karena posisi strategis mereka dalam memobilisasi dukungan," (Asrinaldi, Jurnal, 2017: 5).

"Dalam hal ini niniak mamak melakukan mobilisasi terhadap anak kemenakannya, seperti pada acara kampanye di Imam Bonjol niniak mamak mendatangkan anak keponakan sekitar 200 orang dan siap penuh menyokong Irwan Prayitno dan Nasrul Abit. Kemudian seperti mobilisasi dalam acara rapat atau musyawarah untuk membuat kesepakatan untuk mendukung Irwan Prayitno dan Nasrul Abit," (Suardi Datuak Rajo Bujang, Wawancara, 3 Desember 2019).

Ketiga, pembentukan penghulu jaringan kekuasaan berdasarkan pengakuan dari rekan-rekan mereka dengan menganugerahkan gelar Sangsako di suku. "Pemberian gelar ini masih dilihat sebagai sebuah eksistensi yang harus dimiliki oleh orang-orang yang memiliki keinginan untuk mencalon dalam Pemilu maupun Pilkada, hal ini terlihat dari fenomena yang terjadi di Kecamatan Kuranji setiap anak nagari yang akan mencalon ada upaya untuk meminta gelar, gelar datuk, untuk menambah bahwasanya dia orang Minangkabau," (Yusuf GN Ameh, Wawancara, 02 Desember 2019). "Hal ini juga dilakukan oleh Irwan Prayitno ketika langkah awal untuk mengikuti Pilkada sudah diserahi gelar datuak oleh kaumnya," (Zulhendri Ismet, Wawancara, 5 desember 2019).

Secara eksplisit dapat disimpulkan bahwa jaringan kekuasaan yang digunakan oleh niniak mamak yang tergabung dalam KAN Pauh IX Kecamatan Kuranji ada tiga jaringan, seperti: pertama, jaringan kekuasaan melalui kemampuan pribadi yang diakui oleh masyarakat di desa. Kedua, melalui otoritas tradisional. Ketiga, pembentukan penghulu jaringan kekuasaan berdasarkan pengakuan dari rekan-rekan mereka dengan menganugerahkan gelar Sangsako di suku.

\section{Bentuk Bentuk Dukungan Elit Adat Kecamatan Kuranji}

Dalam melihat keterlibatan niniak mamak atau penghulu dalam Pilkada, Asrinaldi membagi keterlibatan ini dalam empat bentuk. "Pertama, niniak mamak mensosialisasikan calon sesuai dengan kepentingan penghulu kepada anak kemenakannya, terutama menyangkut calon kepala daerah sesuai dengan yang didukungnya. Kedua penghulu dalam Pilkada juga menjadi penghubung kepentingan kaum dan suku dengan calon kepala daerah yang membutuhkan dukungan dari anak kemenakannya di nagari. Ketiga 
mengarahkahkan pilihan anak kemenakannya. Keempat kepemilikan dukungan penghulu adat yang berasal dari anak kemenakannya dalam nagari, juga berimbas pada penguatan legitimasi adat," (Asrinaldi, 2017: 187-189). Berdasarkan hal tersebut tergambar bahwa ada berbagai macam bentuk keterlibatan niniak mamak dalam mendukung pasangan calon di Pilkada.

Bentuk dukungan yang dilakukan oleh niniak mamak yang tergabung dalam KAN Pauh IX Kecamatan Kuranji sebagai berikut.

"Berawal dari kaum suku Irwan Prayitno sendiri, dalam hal ini salah satu bentuk yang dilakukan adalah pemberian gelar Sako kepada Irwan prayitno, pembentukan dewan suku Tanjuang Sumatera Barat yang langsung dipimpin oleh Irwan Prayitno dan menghimbau anak keponakan untuk membuat kesepakatan untuk mendukung Irwan Prayitno maju sebagai Gubernur Sumatera Barat," (Zulhendri Ismet, Wawancara, 5 desember 2019).

"Kemudian setelah Irwan Prayitno bergabung dalam tubuh KAN Pauh IX Kecamatan Kuranji barulah disana dilakukan upaya upaya untuk menggalang dukungan terutama dari niniak mamak yang diawali dengan rapat-rapat kecil di lingkaran niniak mamak," (Suardi Datuak Rajo Bujang, Wawancara, 3 Desember 2019).

"Disamping itu pada tahun 2005 rapat-rapat tersebut dilakukan dibawah BNPN Badan Musyawarah Pembangunan Nagari, dan kantor sekretariat KAN jadi posko pemenangan dan pada tahun 2015 hal itu dilakukan tidak jauh berbeda namun hanya saja intensitasnya berkurang, karena Irwan Prayitno sudah memiliki elektabilitas tinggi dan banyak yang berkeyakinan Irwan Prayitno akan menang dan ada pandangan ketika tidak mendukung Irwan Prayitno sangat akan rugi. (Zulhendri Ismet, Wawancara, 5 Desember 2019).

Berdasarkan hal tersebut KAN Pauh IX Kecamatan Kuranji secara kelembagaan terlibat dalam upaya mendukung Irwan Prayitno. Oleh karena itu bentuk dukungan yang diberikan oleh niniak mamak yang tergabung dalam KAN Pauh IX Kecamatan Kuranji kepada Irwan Prayitno adalah sebagai berikut. Pertama, memberikan gelar Datuak kepada Irwan Prayitno dan pembentukan jaringan suku tanjuang dengan adanya dewan pembina suku Tanjuang Sumatera Barat. Kedua, niniak mamak KAN Pauh IX melakukan konsolidasi untuk mencapai kesepakatan bersama antar niniak mamak yang tergabung dalam KAN Pauh IX Kecamatan Kuranji untuk mendukung Irwan Prayitno dan Nasrul Abit. Ketiga, niniak mamak sebagai penghubung kepentingan antara Irwan Prayitno dengan niniak mamak dan anak keponakan yang ada di Kecamatan Kuranji, hal ini terlihat ketiak ada pertemuan pertemuan yang dilakukan antar niniak mamak dan Irwan Prayitno serta anak nagari. Keempat, niniak mamak mensosialisasikan Irwan Prayitno kepada anak kemenakannya setelah adanya kesepakatan bersama dilingkaran 
niniak mamak yang tergabung dalam KAN Pauh IX Kecamatan Kuranji. Kelima, mobilisasi masa, hal ini dilakukan ketika adanya kegiatan dalam melakukan musyawarah untuk mendukung Irwan Prayitno dan adanya kampanye akbar. Keenam niniak mamak melakukan deklarasi kebulatan tekad bersama anak keponakan secara terbuka di Kecamatan Kuranji untuk mendukung Irwan Prayitno dan Nasrul Abit yang notabenenya ini adalah sebuah bentuk kampanye politik.

Kemudian setelah adanya upaya yang dilakukan oleh niniak mamak yang tergabung dalam KAN Pauh IX Kecamatan Kuranji memiliki dampak terhadap anak kemenakannya di nagari, hal ini dapat dilihat melalui beberapa bentuk dukungan yang dilakukan oleh anak nagari. Pertama, anak nagari menggagas Relawan Dunsanak IP-NA yang diketuai oleh Evi Yandri yang juga ketua FKAN Pauh IX Kecamatan Kuranji. Kedua, penyediaan alat peraga kampanye seperti, spanduk baliho. Ketiga, mensosialisasi Irwan Prayitno dan Nasrul Abit dengan mengadakan pertemuan, mulai dari tingkat RW, kelurahan hingga kecamatan.

\section{KESIMPULAN}

Berdasarkan data dan analisa peneliti dalam studi Dukungan Politik Elit Adat Kecamatan Kuranji Kepada Irwan Prayitno-Nasrul Abit Pada Pilkada Sumbar Tahun 2015. Peneliti dapat menyimpulkan bahwa di dalam Pilkada Sumbar Tahun 2015 Elit Adat Kecamatan Kuranji terlibat di dalam menyokong dan mendukung Irwan Prayitno dan Nasul Abit baik secara Individu maupun melibatkan KAN Pauh IX Kecamatan Kuranji secara kelembagaan. Dalam penelitian ini yang disebut sebagai elit adat adalah Penghulu dan niniak mamak khususnya yang tergabung dalam KAN Pauh IX Kecamatan Kuranji.

Dalam proses keterlibatan niniak mamak dalam memberikan dukungan politik terhadap Irwan Prayitno dilakukan melalui tiga jaringan kekuasaan, yaitu. Pertama, jaringan kekuasaan melalui kemampuan pribadi yang diakui oleh masyarakat di desa. Kedua, pembentukan penghulu jaringan kekuasaan berdasarkan pengakuan dari rekanrekan mereka dengan menganugerahkan gelar Sangsako di suku. Ketiga, melalui otoritas tradisional.

Kemudian bentuk bentuk dukungan politik yang dilakukan oleh niniak mamak yang tergabung dalam KAN Pauh IX Kecamatan Kuranji adalah sebagai berikut: Pertama, memberikan gelar Datuak kepada Irwan Prayitno dan pembentukan jaringan Suku Tanjuang dengan adanya dewan pembina Suku Tanjuang Sumatera Barat. Kedua, niniak mamak KAN Pauh IX melakukan konsolidasi untuk mencapai kesepakatan bersama antar niniak mamak yang tergabung dalam KAN Pauh IX Kecamatan Kuranji untuk mendukung Irwan Prayitno dan Nasrul Abit. 
Ketiga, niniak mamak sebagai penghubung kepentingan antara Irwan Prayitno dengan niniak mamak dan anak keponakan yang ada di Kecamatan Kuranji, hal ini terlihat ketika ada pertemuan pertemuan yang dilakukan antar niniak mamak dan Irwan Prayitno serta anak nagari. Keempat, niniak mamak mensosialisasikan Irwan Prayitno kepada anak kemenakannya setelah adanya kesepakatan bersama dilingkaran niniak mamak yang tergabung dalam KAN Pauh IX Kecamatan Kuranji. Kelima, mobilisasi masa, hal ini dilakukan ketika adanya kegiatan dalam melakukan musyawarah untuk mendukung Irwan Prayitno dan adanya kampanye akbar. Keenam, niniak mamak melakukan deklarasi kebulatan tekad bersama anak keponakan secara terbuka di Kecamatan Kuranji untuk mendukung Irwan Prayitno dan Nasrul Abit yang notabenenya ini adalah salah satu bentuk kampanye politik.

Kemudian setelah adanya upaya yang dilakukan oleh niniak mamak yang tergabung dalam KAN Pauh IX Kecamatan Kuranji memiliki dampak terhadap anak kemenakannya di nagari, hal ini dapat dilihat melalui beberapa bentuk dukungan yang dilakukan oleh anak nagari. Pertama, anak nagari menggagas Relawan Dunsanak IPNA yang diketuai oleh Evi Yandri yang juga ketua FKAN Pauh IX Kecamatan Kuranji. Kedua, penyediaan alat peraga kampanye seperti, spanduk baliho. Ketiga, mensosialisasi Irwan Prayitno dan Nasrul Abit dengan mengadakan pertemuan, mulai dari tingkat RW, kelurahan hingga kecamatan.

\section{DAFTAR PUSTAKA}

\section{Buku}

Asrinaldi. 2017. Demokrasi Lokal Di Indonesia, Padang : Erka.

Burhan bungin. 2011. Penelitian kualitatif. Jakarta: Kencana Prenada Media Group, Djam'an, Satori. 2009. Metode Penelitian Kualitatif. Bandung : Alfabeta.

Imam, Gunawan. 2014. Metode Penelitian Kualitatif: Teori dan Praktik. Jakarta: PT. Bumi Aksara.

John W. Creswell. 2013. Research design pendekatan kualitatif, kuantitatif, dan mixed Edisi ketiga cetakan ke III. Yogyakarta : Pustaka Pelajar.

LKAAM. 2002. Adat Basandi Syarak, Syarak Basandi Kitabullah. Padang: Sako Batuah.

Moleong Lexy J. 2004. Metodologi Penelitian Kualitatif. Bandung : PT. Remaja Rosdakarya.

Sopiah dan Mamang Etta Sngadji. 2010. Metodologi Penelitian. Yogyakarta : CV Andi Offset.

Soerjono Soekanto. 1990. Sosiologi Suatu Pengantar. Jakarta: Rajawali Pers.

Sugiyono. 2016. Metode Penelitian Kuantitatif, Kualitatif, $R \& D$. Alfabeta : Bandung.

Varma, SP. 2010. Teori Politik Modern. Jakarta: Rajawali Pers. 


\section{Skripsi/Jurnal}

Afriani, M Dhany. 2014. "Peran Elit lokal Dalam Konflik Tanah Ulayat Senyarang Kabupaten Tanjung Jabung Barat". Yogyakarta.

Alkahfi. 2014. Peran dan Kontribusi Persatuan Tarbiyah Islamiyah(PERTI) Dalam Perpolitikan di Sumatera Barat(1928-1970). Yogyakarta: UIN Sunan Kalijaga.

Amrianto, 2015, Peran Elit Tradisional Dalam Dinamika Politik Lokal Pada Pemilihan Kepala Daerah di Kabupaten Wakatobi Tahun 2014. Jurnal Politico.

Asrinaldi. 2017. Power Network of Penghulu Adat in The Concurrent Region Election in WestSumatera. Jurnal Ilmu Sosial Ilmu Politik. Vol.21 No.1.

Aulia, Satria Putra. 2014. Peran Elit Dalam Pemenangan Pasangan Baharuddin-Syahru

Pada Pemilukada Pasaman Barat Tahun 2010. Diploma Thesis. Universitas Andalas.

Nike K Rumokoy, 2016, Pelaksanaan Pemilihan Bupati dan Wakil Bupati Sebelum Setelah Berlakunya UU No 9 Tahun 2015, Jurnal Hukum Unsrat. Vol.22NO.6.

Nur Aliyah z dan Ibnu Khaldum.. 2017. Local Strongmen dan kontestasi politik (studi terhadap kemenangan fenomenal aras tammmauni dan muh. Amin jasa pada pilkada mamuju tengah.) Skripsi. Gowa: Uin Allaudin Makassar.

Windy Astuti, 2014, Keluarga Berencana Dalam Persepsi Kader Partai Keadilan Sejahtera (Studi Pada Keluarga Kader PKS di Desa Candimas Natar, Skripsi dari jurusan Sosiologi Fakultas Ilmu Sosial Ilmu Politik Universitas Lampung.

Yulia Mirwati, Irzal Rias. 2018. Peran Kerapatan Adat Nagari (KAN) dalam Menyelesaikan Sengketa Tanah Adat di Kecamatan Kuranji. Tesis. Universitas Andalas.

\section{Berita}

Haluan. 2016, 1 maret. Kampung Adat Dikembangkan di Kuranji. Diakses melalui : https://www.harianhaluan.com/news/detail/49382/kampung-adat-dikembangkan-dikuranji pada 15 April 2019.

MinangkabauNews. 2019. 5 desember. Ninik Mamak KAN Pauh V dan IX Sepakat Dukung IP-NA. Diakses melalui : https://minangkabaunews.com/artikel-7157ninik- mamak-kan-pauh-v-dan-ix-sepakat-dukung-ipna.html pada 3 November 2018.

Zamri Yahya.2015. 4 Desember. Ketika Niniak Mamak dan Anak Nagari Menyatakan Kebulatan Tekad Dukung kepada IP-NA. Diakses melalui http://irwanprayitno.com/2015/12/ketika-ninik-mamak-dan-anak-nagari-nyatakan-kebulatantekad- dukung-ip-na/ pada 2 Maret 2018. 